\title{
Research on Influence of Zeolite Powder on Internal Humidity and Autogenous Shrinkage of Self-Compacting concrete
}

\author{
WEN Chaokai, CHEN Jing, LIU Qibin \\ China West Construction Southwest Group Co., Ltd. Chengdu 610052, China
}

\begin{abstract}
Keywords: Self-Compacting Concrete, Internal Humidity, Autogenous Shrinkage
Abstract: The influence of zeolite powder on humidity, autogenous shrinkage and mechanical properties inside the self-compacting concrete as the self-curing material are researched. The addition amount of zeolite powder is $0 \%, 2 \%, 4 \%$ and $8 \%$ respectively, the results show that selfcompacting concrete with zeolite pow-der as self-curing materials can improve the slump loss. When addition is $2 \%$, it have influence on compressive strength at early age and less influence at later age. Compared with benchmark self-compacting concrete, when internal relative humidity decreases from $100 \%$ to $90 \%$, it takes $4 \mathrm{~d}$ for benchmark self-compacting concrete while selfcompacting concrete with $2 \%, 4 \%$ and $8 \%$ zeolite powder respectively takes $6 \mathrm{~d}, 14 \mathrm{~d}$ and $24 \mathrm{~d}$. Selfcompacting concrete with zeolite powder addition is $2 \%, 4 \%$ and $8 \%$, autogenous shrinkage of $2 \mathrm{~d}$ respectively decrease $21.4 \%, 34.9 \%$ and $57.3 \%$ and $7 \mathrm{~d}$ autogenous shrinkage respectively decrease $12.6 \%, 26.8 \%$ and $39.4 \%$ compared with benchmark self-compacting concrete.
\end{abstract}

\section{Introduction}

With the development of society, the high-rise, super high-rise buildings are gradually increased. The high-strength concrete and self-compacting concrete has become the trend of development of concrete industry (LIU Yunhua, 2007 \& ZHAO Jun, 2003). Self-compacting concrete has significant advantages in reducing construction costs and improve construction environment, etc. (LI Yue, 2005 \& OZAWA K, 1989). In order to meet the demand of workability and strength of self-compacting concrete, low water consumption, high amount of cementitious material and the active mineral admixture become the key technology for preparation of self-compacting concrete. Due to the use of high amount of cement and low water consumption, the autogenous shrinkage becomes higher, thus easy to cause shrinkage cracking and affect the structural safety of building (YANG Yuhong, 2010).

Internal relative humidity of concrete fall is caused by high-strength self-compacting concrete produced from the root causes of autogenous shrinkage. How to improve and enhance the internal humidity of concrete has become an important method to solve high-strength self-compacting concrete autogenous shrinkage.

Previous study showed that self-curing materials can reduce the autogenous shrinkage of highstrength self-compacting concrete. At present, self-curing materials mainly have SAP and lightweight aggregate, but they all have their own disadvantages to limit their use. The porous powder--zeolite powder is as new self-curing materials gradually coming into our sight. The influence of zeolite powder on humidity, autogenous shrinkage and mechanical properties inside the concrete as the self-curing material is studied, which provides a technical basis for preparation of self-curing high-performance concrete.

\section{Experiment}

\subsection{Raw materials}

Cement: P.O42.5 cement produced by Sichuan Lafarge are used in the test. Their basic performance is shown in table 1 . 
Table 1: Basic performance of cement

\begin{tabular}{cc}
\hline Index & Result \\
\hline Specific area & $334 \mathrm{~m}^{2} / \mathrm{kg}$ \\
Flexural Strength(3d) & $5.6 \mathrm{MPa}$ \\
Flexural Strength(28d) & $8.9 \mathrm{MPa}$ \\
Compressive strength $(3 \mathrm{~d})$ & $27.1 \mathrm{MPa}$ \\
Compressive strength(28d) & $50.9 \mathrm{MPa}$ \\
Density & $3.12 \mathrm{~g} / \mathrm{cm}^{3}$ \\
Stability & Conforming \\
\hline
\end{tabular}

Fly ash: Grade I fly ash are used in the test. Their basic properties are as follows: fineness of $6.5 \%, \mathrm{SO}_{3}$ addition of $0.69 \%$, loss on ignition of $1.9 \%$, water requirement $95 \%$.

Slag: S95 slag are used in the test. Their basic properties are as follows: loss on ignition of $0.71 \%$, fluidity ratio of $100 \%$, density of $2.88 \mathrm{~g} / \mathrm{cm}^{3}$, specific surface area of $457 \mathrm{~m}^{2} / \mathrm{kg}$.

Silica fume: Silica fume is, when collected, an ultrafine powder having the following basic properties: $\mathrm{SiO}_{2}$ addition at least $90 \%$, specific surface area of $16115 \mathrm{~m}^{2} / \mathrm{kg}$.

Zeolite Powder: Zeolite Powder as a kind of new-type self-curing materials. Their basic properties are as follows: density of $2.41 \mathrm{~g} / \mathrm{cm}^{3}$, specific surface area of $701 \mathrm{~m}^{2} / \mathrm{kg}$, water requirement $124 \%$, and fluidity ratio of $69 \%$.

(6)Machine-Made Sand: Fineness modulus of 2.7 , apparent density $2740 \mathrm{~kg} / \mathrm{m}^{3}$, mud addition of $0.3 \%$.

Gravel: $5 \sim 20 \mathrm{~mm}$ gravel are used in the test, mud addition of $0.5 \%$, apparent density $2710 \mathrm{~kg} / \mathrm{m}^{3}$, crushing value of $7.9 \%$.

Superplasticizer: Polycarboxylate superplasticizer are used in the test. Solid addition of $20.1 \%$, water reducing ratio of $29 \%$.

\subsection{Mix Design}

The influence law of zeolite powder on self-compacting concrete workability, mechanical properties, internal humidity and shrinkage is studied for the purpose of analyzing mechanism of its influence on self-compacting concrete. The addition amount of zeolite powder is $0 \%, 2 \%, 4 \%$ and $8 \%$ respectively. Test mix proportion is shown in table 2 .

Table 2: Testing mix proportion of self-compacting concrete with zeolite powder (Unit: $\mathrm{kg} / \mathrm{m} 3$ )

\begin{tabular}{ccccc}
\hline No & SCC-1 & SCC-2 & SCC-3 & SCC-4 \\
\hline Cement & 330 & 330 & 330 & 330 \\
Fly ash & 160 & 148 & 136 & 112 \\
Slag & 80 & 80 & 80 & 80 \\
Silica fume & 30 & 30 & 30 & 30 \\
Zeolite powder & 0 & 12 & 24 & 48 \\
Sand & 760 & 760 & 760 & 760 \\
Gravel & 920 & 920 & 920 & 920 \\
Water & 144 & 144 & 144 & 144 \\
Superplasticizer & 9.0 & 9.0 & 9.5 & 10.2 \\
\hline
\end{tabular}

\section{Results and analysis}

\subsection{Influence of zeolite powder on workability of self-compacting concrete}

The influence of zeolite powder on self-compacting concrete slump, inverted slump cone and Ubox is studied for analyzing of its influence on self-compacting concrete workability. The addition amount of zeolite powder is $0 \%, 2 \%, 4 \%$ and $8 \%$ respectively. Test mix proportion is shown in table 2 and the test result is shown in table 3.

Table 3 shows the influence of zeolite powder on self-compacting concrete workability. By conducting analysis on Table 3, we know that with increase of zeolite powder addition amount, 
self-compacting concrete slump flow reduce gradually from $700 \mathrm{~mm}$ to $580 \mathrm{~mm}$ and U-box increases gradually from $10 \mathrm{~mm}$ to $170 \mathrm{~mm}$. This shows that zeolite powder is not conducive to workability of self-compacting concrete.

Workability loss result shows that self-compacting concrete with zeolite powder as self-curing materials can improve the slump loss. $2 \mathrm{~h}$ workability of self-compacting concrete with $2 \%$ zeolite powder addition is better than benchmark self-compacting concrete, when the zeolite powder addition of more than $4 \%$, although self-compacting concrete slump and inverted slump cone has been improved, but still flow properties far less than the benchmark self-compacting concrete. Therefore, in order to ensure a good workability of self-compacting concrete, zeolite powder addition is not to over $4 \%$. That is because major components of zeolite powder is porous vitreous, some water absorbed earlier will release as hydration prolongs, then workability of self-compacting concrete can improves. Besides, zeolite power has good water conservation effect, therefore, can improve the slump loss.

Table 3: Influence of zeolite powder on workability of self-compacting concrete

\begin{tabular}{ccccc}
\hline No & SCC-1 & SCC-2 & SCC-3 & SCC-4 \\
\hline Index & & & & \\
\hline Slump(0h) & $270 \mathrm{~mm}$ & $260 \mathrm{~mm}$ & $255 \mathrm{~mm}$ & $240 \mathrm{~mm}$ \\
Slump(2h) & $265 \mathrm{~mm}$ & $275 \mathrm{~mm}$ & $270 \mathrm{~mm}$ & $245 \mathrm{~mm}$ \\
Slump flow(0h) & $700 \mathrm{~mm}$ & $670 \mathrm{~mm}$ & $635 \mathrm{~mm}$ & $580 \mathrm{~mm}$ \\
$\begin{array}{c}\text { Slump flow(2h) } \\
\text { Inverted slump }\end{array}$ & $680 \mathrm{~mm}$ & $685 \mathrm{~mm}$ & $660 \mathrm{~mm}$ & $600 \mathrm{~mm}$ \\
$\quad 3.6 \mathrm{~s}$ & $5.3 \mathrm{~s}$ & $9.3 \mathrm{~s}$ & $13.2 \mathrm{~s}$ \\
$\begin{array}{c}\text { Inverted slump }(0 \mathrm{~h}) \\
\text { cone(2h) }\end{array}$ & $4.2 \mathrm{~s}$ & $5.1 \mathrm{~s}$ & $8.5 \mathrm{~s}$ & $12.2 \mathrm{~s}$ \\
U-box(0h) & $10 \mathrm{~mm}$ & $10 \mathrm{~mm}$ & $80 \mathrm{~mm}$ & $170 \mathrm{~mm}$ \\
\hline
\end{tabular}

\subsection{Influence of zeolite powder on compressive strength of self-compacting concrete}

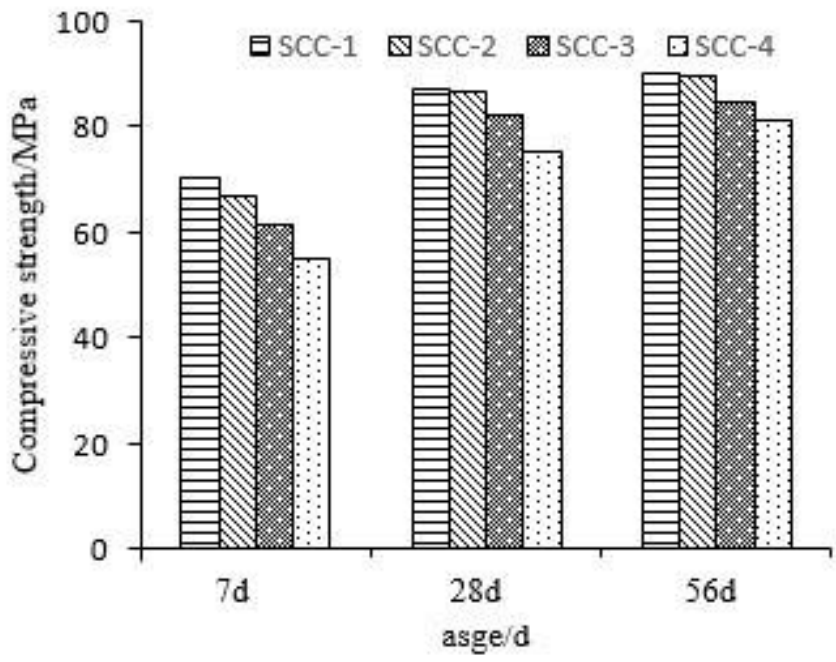

Figure 1: Influence of zeolite powder on mechanical property of self-compacting concrete

Figure 1 shows influence of zeolite powder on mechanical property of self-compacting concrete. According to this figure, self-compacting concrete with zeolite powder has a great influence on compression strength. When addition is $2 \%, 4 \%$ and $8 \%$, compressive strength of self-compacting concrete decreased significantly and the more zeolite powder is, the lower compressive strength will be. Especially for early strength will decline rapidly as zeolite amount increases. When it curing $7 \mathrm{~d}$ age, compared with benchmark self-compacting concrete, compressive strength will decline $3.9 \mathrm{MPa}$, but when curing $56 \mathrm{~d}$ age, it only decreased $0.5 \mathrm{MPa}$. When the zeolite content of $4 \%$ and $8 \%$, the $7 \mathrm{~d}$ compressive strength decreased $9.2 \mathrm{MPa}$ and $15.5 \mathrm{MPa}, 56 \mathrm{~d}$ compressive 
strength decreased 5.6MPa and 9.2MPa. Test results show that zeolite powder will have greater influence on compressive strength of self-compacting concrete, but when addition is $2 \%$, it have influence on compressive strength at early age and less influence at later age. Therefore, in order to ensure compressive strength of self-compacting concrete with zeolite powder should be less than $4 \%$.

\subsection{Influence of zeolite powder on internal humidity of self-compacting concrete}

This test designs for zeolite powder addition up $0 \%, 2 \%, 4 \%$ and $8 \%$ to research on influence of zeolite powder on internal humidity of self-compacting concrete. Figure 2 shows influence of zeolite powder on internal relative humidity of self-compacting concrete. According to figure 2, internal relative humidity of self-compacting concrete with a big decline in early curing age, when zeolite powder addition in self-compacting concrete, the internal relative humidity of selfcompacting concrete increase gradually and the addition increases the higher internal relative humidity. Compared with benchmark self-compacting concrete, self-compacting concrete with $8 \%$ zeolite powder addition shows slower decrease in internal relative humidity of self-compacting concrete.

According to figure 2, compared with benchmark self-compacting concrete, when internal relative humidity decrease $100 \%$ to $90 \%$, benchmark self-compacting concrete takes $4 \mathrm{~d}$ while selfcompacting concrete with $2 \%, 4 \%$ and $8 \%$ zeolite powder respectively takes $6 \mathrm{~d}, 14 \mathrm{~d}$ and $24 \mathrm{~d}$, which means zeolite powder addition can increase internal relative humidity of self-compacting concrete at same curing age. This is because zeolite internal porous structure can absorb and reservoir water for self-compacting concrete. As hydration time increases, water in zeolite powder releases gradually which increase internal relative humidity of self-compacting concrete. It shows that zeolite powder as self-curing materials have good curing effect, which can increases internal relative humidity of self-compacting concrete.

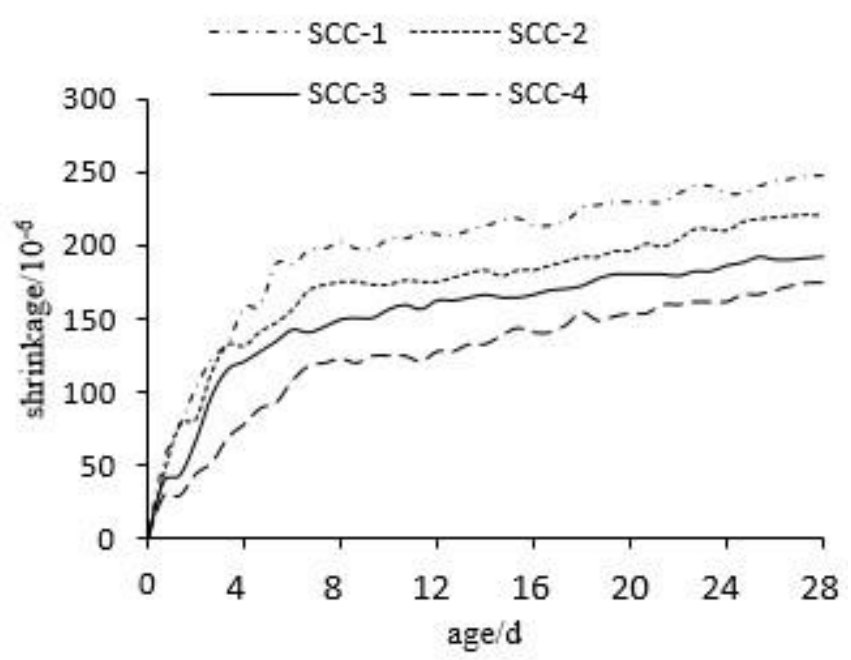

Figure 2: Influence of zeolite powder on relative humidity of self-compacting concrete 


\subsection{Influence of zeolite powder on autogenous shrinkage of self-compacting concrete}

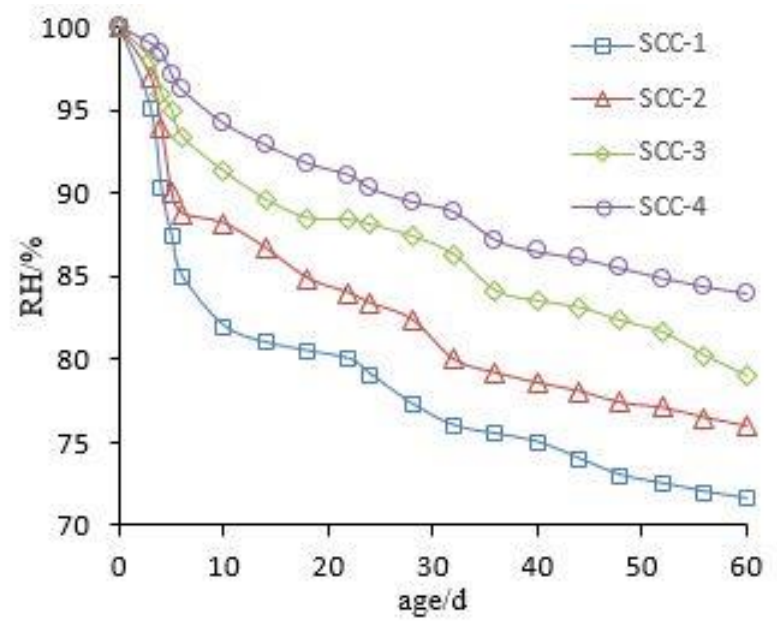

Figure 3: Influence of zeolite powder on autogenous shrinkage of self-compacting concrete

Figure 3 shows influence of zeolite powder on autogenous shrinkage of self-compacting concrete, according to figure 3, all group self-compacting concrete, autogenously shrinkage mainly happens in early curing age. As curing age increases, autogenous shrinkage of self-compacting concrete, specimen gradually tends to be stable. When zeolite powder addition is $2 \%, 4 \%$ and $8 \%$, autogenous shrinkage of $2 \mathrm{~d}$ zeolite powder self-compacting concrete respectively decrease $21.4 \%$, $34.9 \%$ and $57.3 \%$ and $7 \mathrm{~d}$ autogenous shrinkage respectively decrease $12.6 \%, 26.8 \%$ and $39.4 \%$ compared with benchmark self-compacting concrete. Therefore, zeolite powder can decreases the autogenous shrinkage of self-compacting concrete. This is because water in zeolite powder internal porous structure releases gradually with curing, compensate water lost cause internal relative humidity decreases of self-compacting concrete, and decreases autogenous shrinkage of selfcompacting concrete.

\section{Conclusion}

Self-compacting concrete with zeolite powder as self-curing materials, can improve the slump loss. According to test result, self-compacting concrete with zeolite powder has a big influence on compression strength, but when addition is $2 \%$, it has influence on compressive strength at early age and less influence at later age. Therefore, in order to ensure compressive strength of selfcompacting concrete with zeolite powder should be less than $4 \%$.

When zeolite powder is added in self-compacting concrete, the internal relative humidity of selfcompacting concrete increases gradually and the addition increases the higher internal relative humidity. Compared with benchmark self-compacting concrete, when internal relative humidity decrease $100 \%$ to $90 \%$, benchmark self-compacting concrete takes $4 \mathrm{~d}$ while self-compacting concrete with $2 \%, 4 \%$ and $8 \%$ zeolite powder respectively takes $6 \mathrm{~d}, 14 \mathrm{~d}$ and $24 \mathrm{~d}$, which means zeolite powder addition can increase internal relative humidity of self-compacting concrete at same curing age.

The test results show that zeolite powder can reduce the autogenous shrinkage of selfcompacting concrete. When zeolite powder addition is $2 \%, 4 \%$ and $8 \%$, autogenous shrinkage of $2 \mathrm{~d}$ zeolite powder self-compacting concrete respectively decrease $21.4 \%, 34.9 \%$ and $57.3 \%$ and $7 \mathrm{~d}$ autogenous shrinkage respectively decrease $12.6 \%, 26.8 \%$ and $39.4 \%$ compared with benchmark self-compacting concrete. 


\section{References}

[1] LIU Yunhua, XIE Youjun, LONG Guangcheng. Progress of research on Self-compacting concrete. J. Journal of the Chinese Ceramic Society. 2007, 35(05):671-678.

[2] ZHAO Jun. The Research and Application of Self-compacting Concrete. J. Concrete. 2003(06):9-17.

[3] LI Yue, JIN Caiyun. Study on the Mechanical Properties of Expansive Concrete Filled Steel Tube. J. Construction Technology. 2005(S2):47-50.

[4] OZAWA K, MAEKAWA K, KUNISHIMA M, et al. Development of high performance concrete based on the durability design of concrete structures .A. The Second East-Asia and Pacific Concrete on Structural Engineering and Construction (EASEC-2) .C. Tokyo, Japan, 1989. 445-450.

[5] YANG Yuhong, LI Yue, DU Xiuli. Study on Early Autogenous shrinkage and Microcosmic Pore Distribution of Self-compacting Concrete. J. Journal of Building Materials. 2010, 13(05):601-606. 